\title{
ГЕНДЕРНІ ОСОБЛИВОСТІ РЕГУЛЯЦІЇ СЕРЦЕВОГО РИТМУ У ВІЙСЬКОВОСЛУЖБОВЦІВ В УМОВАХ ДІЇ ІНФОРМАЦІЙНОГО СТРЕСУ РІЗНОЇ ІНТЕНСИВНОСТІ
}

\author{
А.В. Швець
}

Українська військово-медична академія (м. Київ)

\begin{abstract}
Актуальність. Вивчення гендерних особливостей впливу інформаційного стресу різної інтенсивності на регуляторні функції організму військовослужбовців $є$ актуальним у зв'язку набуттям чинності Закону про рівні права жінок і чоловіків на військовій службі у Збройних Силах України та інших військових формуваннях та активним залученням жінок військовослужбовців до екстремальних умов службової діяльності.
\end{abstract}

Мета роботи - виявлення гендерних особливостей змін варіабельності серцевого ритму у військовослужбовців, які знаходяться в стані підвищеного нервово-емоційного напруження внаслідок впливу інформаційного стресу різної інтенсивності.

Матеріали та методи. Досліджено 73 здорових військовослужбовці жіночої та чоловічої статті віком 22-25 років (з них 58\% чоловіки). Для вирішення поставленої мети розроблено адекватну модель стресогенного впливу, де у якості стресогенного навантаження використовували дію інформаційного чинника різної інтенсивності. Вивчення варіабельності серцевого ритму проводили за допомогою апаратно-програмного комплексу "Cardio Sens» до застосування інформаційного навантаження, протягом обробки людиною різної за складністю та змістом інформації, а також після інформаційного навантаження. Аналіз отриманих результатів проводився методами варіаційної статистики, дисперсійного аналізу за допомогою пакета програм STATISTICA 8.0.

Результати. Встановлено, що у жінок стрес-індекс до початку процедури тестування та під час виконання завдань на якість динамічного запам'ятовування вищий майже у 2 рази за показники у чоловіків (p<0,001), що свідчить про більшу стресочутливість у жінок. Відмінною особливістю в структурі спектральної потужності високочастотних хвиль (HF) у жінок $\epsilon$ підвищена вагусна активність перед початком тестування, а у чоловіків вагусна активність превалює наприкінці і після його закінчення, що свідчить про більш тривалішу активність симпатичної нервової системи у них. Встановлені особливості варіабельності серцевого ритму у військовослужбовців в умовах дії інформаційного стресу різної інтенсивності обумовлюють меншу ймовірність розвитку надлишкової реакції з боку серцево-судинної системи у чоловіків під час дії інформаційного чинника, про що свідчить превалювання парасимпатичного автономного контуру регуляції серцевого ритму над центральним наприкінці усього періоду інформаційного навантаження.

Висновки. Доведено, що ціна адаптації до інформаційного стресу у жінок-військовослужбовців $\epsilon$ суттєво вищою при комбінованому когнітивному та темпоральному інформаційному навантаженні у порівнянні з чоловіками. При цьому відмічено також значиме напруження регуляторних функцій перед незвичними та заздалегідь невідомими умовами діяльності (тестове навантаження). Встановлені особливості впливу інформаційного стресу на енергетичному рівні організації організму військовослужбовиів різної статі можуть стати підгрунтям для удосконалення психофізіологічного супроводу та виявлення психофізіологічних механізмів забезпечення високої надійності професійної діяльності військовослужбовців і, зокрема жінок, при їх направленні в реальні екстремальні умови виконання службових обов'язків.

Ключові слова: варіабельність серцевого ритму, психофізіологічний стан, гендерні особливості, інформаційний стрес, військовослужбовці.

Вступ. Ще на початку досліджень 3 варіабельності серцевого ритму (ВСР) була розпочата спроба використати аналіз ВСР для вивчення реакції організму на стресові впливи та оцінки виразності цієї реакції. Результати таких досліджень були опубліковані в монографії [1]. Надалі ці й інші дослідники неодноразово поверталися до даної проблеми. В останнє десятиліття в наукових i клінічних дослідженнях зріс інтерес до використання показників ВРС як інтегрального критерію функціонального стану організму. У літературі висвітлюється висока інформативність вивчення ВСР для оцінки стресових реакцій серцево-судинної системи при фізичних й емоційних навантаженнях $[1,3,6,10,12,14,15,16]$. У той же час недостатньо освітлені гендерні аспекти змін ВСР в умовах інформаційного стресу у військовослужбовців. У зв'язку 3 
набуттям чинності Закону про рівні права жінок і чоловіків на військовій службі у Збройних Силах України та інших військових формуваннях (№ 2523-VIII) та активним залученням жінок військовослужбовців до екстремальних умов службової діяльності вивчення гендерних особливостей впливу інформаційного стресу різної інтенсивності на регуляторні функції організму військовослужбовців $є$ актуальним.

Складність цього наукового вивчення, зокрема у гендерному аспекті, додатково обумовлюється багатовимірністю проявів феноменології індивідуальності військовослужбовців, а результати досліджень мають поліморфний характер та модальну не специфічність [17].

Так, на статеві розходження показників ВРС указується в окремих дослідженнях $[2,4,8,13]$. У одній із робіт говориться про якісні статеві розходження показників ВРС і системного артеріального тиску [4]. Інше дослідження [13] представляє статеві відмінності ВРС як «знахідку». Автори вважають, що зниження симпатичного тонусу в жінок $\epsilon$ пристосувальною захисною реакцією, що знижує аритмогенний ризик [13]. Л. М. Бакусовим із співавторами показано переваги методів нелінійного аналізу ВРС у виявленні статевих відмінностей [2] . У фундаментальній роботі Н. Б. Хаспекової зроблений висновок про те, що «коливальна структура РС у здорових не залежить від статі», але в самому дослідженні неодноразово вказується на існування гендерних відмінностей вегетативної реактивності [8].

Тому метою роботи $\epsilon$ виявлення гендерних особливостей змін ВСР у військовослужбовців, які знаходяться в стані підвищеного нервово-емоційного напруження внаслідок впливу інформаційного стресу різної інтенсивності.

Матеріали та методи досліджень. Досліджувану вибірку складали 73 здорових військовослужбовці жіночої та чоловічої статті віком 22-25 років (з них 58\% чоловіки). Для вирішення поставленої мети розроблено адекватну модель стресогенного впливу, де у якості стресогенного навантаження використовували інформаційний чинник різної інтенсивності. Вплив інформаційного стресу різної інтенсивності на військовослужбовців забезпечували за допомогою декількох прийомів: 1. - окремі елементи тестових психофізіологічних завдань подавались 3 різним рівнем складності, причому послідовність зміни складностей була непередбачуваною (подавалась 3 однаковою вірогідністю); 2. темп пред'явлення завдань був на рівні і вище максимального темпу індивідуальної спроможності вирішення завдань.

Застосовували психофізіологічні завдання, де оцінювались: швидкість і точність реакції на рухомий об’єкт (РPO), якість динамічного запам'ятовування (ЯДЗ), концентрація уваги та обсяг короткочасної пам'яті (КУКП). Для цього було створено комп'ютерну методику для оцінки цих психофізіологічних параметрів, яка детально описана раніше [5]. Цей захід підсилював нервово-емоційне напруження за рахунок: ліміту часу на вирішення завдань при такій організації випробування, високим мотиваційним компонентом випробуваних (дослідження проводились у ситуації професійного добору), нестандартністю ситуації. Таким чином, в роботі було використано широкий спектр тестів, які імітували переробку інформації оператором: одні 3 тестів були спрямовані на випробування першої сигнальної системи (РРО та ЯДЗ), інші - на випробування другої (КУКП). В деяких тестах домінуючим було випробування швидкісних якостей при переробці інформації (РРО), в інших доповнювалось навантаженням на короткочасну пам'ять. Для полегшення засвоєння і виконання зазначених методик була використана процедура вироблення альтернативних рішень «ТАК-НІ», коли досліджуваний у відповідь на подразник у будь-якому випадку повинен був натискувати одну 3 двох клавіш. Кожне дослідження проводилось у три етапи. Перший етап був навчальний, коли перевірялась якість засвоєння досліджуваним змісту випробувальної процедури.

$$
\text { Сутністю наступного етапу було }
$$
пред'явлення завдання в режимі зі «зворотним зв'язком» (в залежності від правильності відповіді), а саме: швидкості руху стрілки та зміні часової експозиції сигналу на 5\% у методиках РРО та ЯД3; зміні на одиницю кількості символів (обсягу 
запам'ятовування) у методиці КУКП при виробленні двох підряд вірних чи невірних відповідей. Дана процедура була проведена для встановлення «точки індивідуального оптимального рівня» (К) когнітивного навантаження при вирішенні завдань.

Для наближення умов експерименту до «критичних» (стресових) за своїм інформаційним навантаженням рівнів проводився третій етап тестування (за рахункове тестування), який складався 3 низки випробувань 3 чотирма різними рівнями складності завдань. При чому, друга складність завдання відповідала виявленому в другому етапі найкращому результату для кожної 3 застосованих методик. Отже, складність завдань змінювалася щодо точки $K$, і наступні чотири завдання пред'являлися відповідно зі складністю: К- $, \mathrm{K}, \mathrm{K}+\kappa, \mathrm{K}+2 \kappa$ (де $\kappa$ - постійний крок зміни складності завдання). Пред'явлення завдань з різними рівнями складності здійснювалось випадково 3 однаковою ймовірністю. Кількість завдань кожної складності була однаковою. Нервовоемоційне напруження додатково підсилювалось за рахунок: ліміту часу на вирішення завдань при такій організації випробування, високим мотиваційним компонентом випробуваних (дослідження проводились у ситуації професійного добору), нестандартністю ситуації.

Ступінь складності завдань визначався: для ЯДЗ - зміною експозиції пред'явлення кольорових сигналів на 0,1 с.; для РРО - зміною швидкості руху стрілки на 1 см/с в залежності від точності попадання у 5мм довірчий інтервал; для КУКП - зміною на одиницю кількості символів (літер та чисел) у символьному ряді, що пред'являвся досліджуваному.

Вивчення стану вегетативної нервової системи здійснювалось відповідно до загальноприйнятих стандартів аналізу варіабельності серцевого ритму (ВСР) [11] за допомогою апаратно-програмного комплексу «Cardio Sens» виробництва фірми «XAIМедика». Дослідження показників ВСР здійснювалось до застосування психофізіологічної тестової процедури, протягом виконання кожного 3 трьох психофізіологічних тестів, та після них.

Дослідження проводились на підставі інформованої згоди щодо участі у обстеженні у відповідності до Гельсинської декларації. Дизайн дослідження узгоджено $з$ комісією 3 біоетики Української військово-медичної академії. Аналіз отриманих результатів проводився методами варіаційної статистики, дисперсійного аналізу за допомогою пакета програм STATISTICA 8.0.

Результати дослідження. Зміни функціонального стану на енергетичному рівні організації організму у чоловіків та жінок свідчать про більший рівень прояву нервово-емоційного напруження $\mathrm{y}$ військовослужбовців жінок.

Виявлено, що навіть до початку тестового навантаження емоційне напруження $\mathrm{y}$ чоловіків призводить до достовірно вищих значень показників ВСР $(\mathrm{mRR}-863,41 \pm 19,30, \mathrm{p}<0,001 ; \quad$ SDNN $52,00 \pm 3,14, \mathrm{p}<0,05)$, аналогічних показників у жінок (відповідно - 763,31 $\pm 16,88 ; 41,14 \pm 2,71$ ). Рівень показника SI $(153,63 \pm 10,56 ; p<0,01)$ у чоловіків суттєво нижчий ніж у осіб жіночої статі - 261,31 40,37 ( рис 1 ).

Подібні особливості виявлені і при дослідженні показників ВСР під час виконання найбільш складного для виконання тесту на ЯДЗ. Так, стрес-індекс у осіб жіночої статі під час тесту ЯДЗ вищий за показники у чоловіків (відповідно SI жінок $398,54 \pm 59,90$ та $206,86 \pm 20,24$ у чоловіків), рівні показників $\mathrm{mRR}$ та SDNN теж суттєво вищі у чоловіків ніж у жінок.

Подальші заміри показників ВСР вказують на їх відносну стабілізацію, що свідчить про певне вирівнювання енергетичного обміну між досліджуваними особами при вирішенні завдань меншої складності, однак тенденція щодо більших енергетичних затрат у жінок зберігається.

Особливості зміни потужності частотних характеристик ВСР у чоловіків та жінок наведено в табл. 1.

При поділі досліджуваних груп за статевою ознакою виявлено, що до початку тестового навантаження у чоловіків показник ULF $(27,49 \pm 7,47 ; \mathrm{p}<0,05), \operatorname{LF}(1306,95 \pm 167,36$; $\mathrm{p}<0,05) \quad$ та $\quad$ VLF $(753,93 \pm 124,67 ; \quad \mathrm{p}<0,05)$ достовірно перевищують аналогічні показники у жінок (відповідно $-11,21 \pm 2,71$;; $815,66 \pm 130,13$ та 397,52 $\pm 53,73)$. Подібні особливості виявлені і при дослідженні показників ВСР під час тесту на ЯДЗ. Однак тут почали проявлятися зміни у структурі 
частотних характеристик. Так у чоловіків доля $\operatorname{VLF}(46,10 \pm 3,28 ; \mathrm{p}<0,05)$ достовірно вище ніж у жінок (відповідно 35,73 $\pm 3,02$ ), разом 3 цим доля $\mathrm{HF}$ у останніх достовірно вища $(25,09 \pm 1,88 ; \quad$ p $<0,01, \quad$ у порівнянні 3 чоловіками $17,66 \pm 1,73)$.
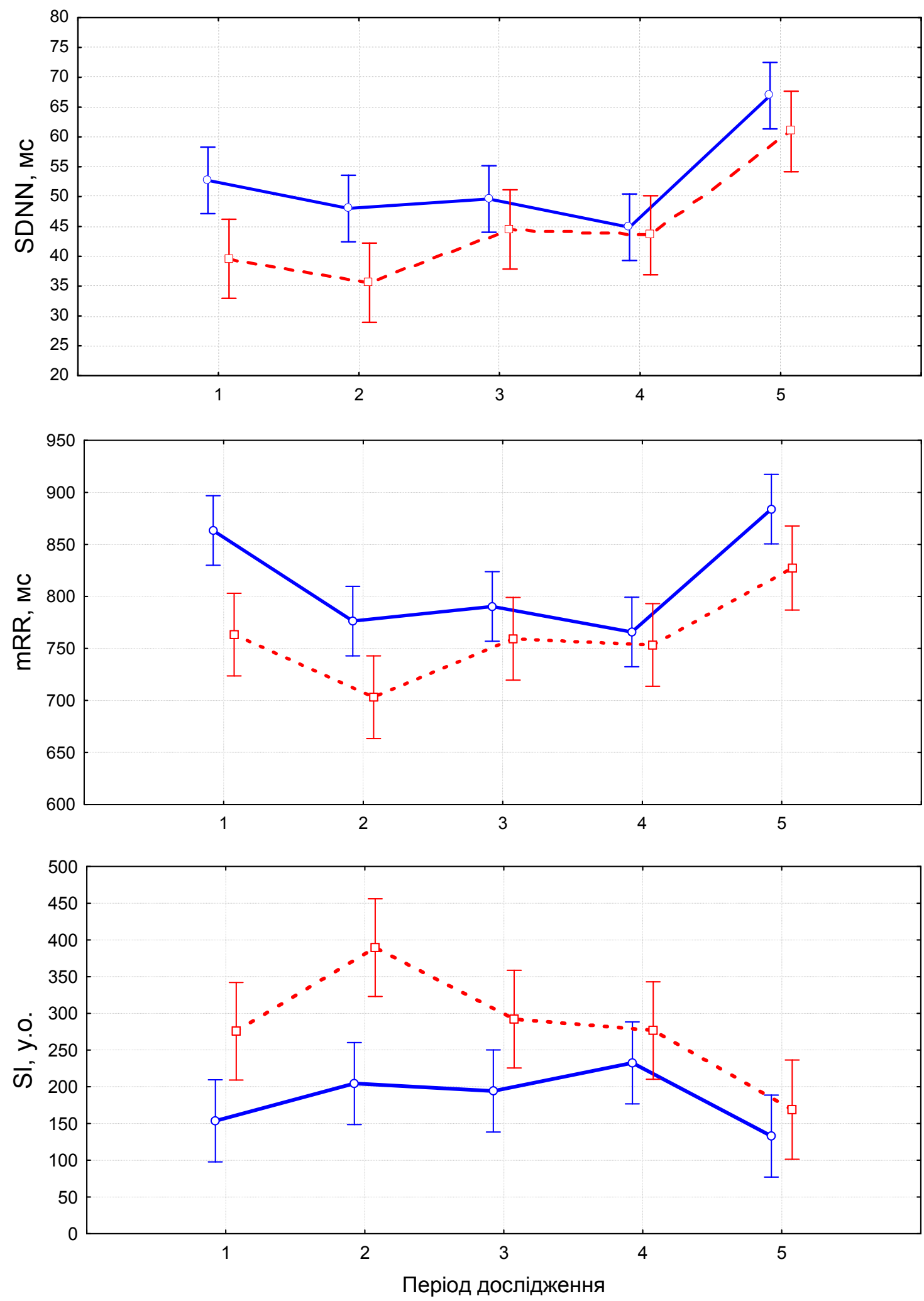

三 Група чоловіків; - 호- Група жінок

Рисунок 1. Гендерні особливості варіабельності серцевого ритму в різні періоди: 1- до тестового навантаження, 2 - під час тесту на ЯДЗ, 3 - під час тесту на РPO, 4 - під час тесту на КУКП, 5 - після тестового навантаження. 
Таблиця 1.

Гендерні особливості показників ВСР в стресових умовах

\begin{tabular}{|c|c|c|c|c|c|c|}
\hline Показники & $\stackrel{\stackrel{0}{E}}{\stackrel{E}{H}}$ & $\begin{array}{c}\text { До тестового } \\
\text { навантаження }\end{array}$ & $\begin{array}{c}\text { Під час тесту на } \\
\text { ЯД3 }\end{array}$ & $\begin{array}{c}\text { Під час тесту на } \\
\text { РPO }\end{array}$ & $\begin{array}{c}\text { Під час тесту } \\
\text { на КУКП }\end{array}$ & $\begin{array}{c}\text { Після тестового } \\
\text { навантаження }\end{array}$ \\
\hline \multirow{2}{*}{ ULF, $\mathrm{Mc}^{2}$} & ч & $27,49 \pm 7,47^{*}$ & $20,83 \pm 3,19 *$ & $35,15 \pm 13,36$ & $17,32 \pm 3,43$ & $64,12 \pm 14,53$ \\
\hline & Ж & $11,21 \pm 2,71$ & $9,93 \pm 3,35$ & $14,45 \pm 3,27$ & $17,66 \pm 4,05$ & $60,14 \pm 27,67$ \\
\hline \multirow{2}{*}{ VLF, $\mathrm{MC}^{2}$} & ч & $753,93 \pm 124,67^{*}$ & $1120,12 \pm 182,23^{* *}$ & $1028,83 \pm 246,35$ & $532,63 \pm 81,16$ & $1396,12 \pm 188,89$ \\
\hline & Ж & $397,52 \pm 53,73$ & $507,07 \pm 109,16$ & $906,55 \pm 72,25$ & $581,24 \pm 108,00$ & $1781,61 \pm 562,34$ \\
\hline \multirow{2}{*}{$\mathrm{HF}, \mathrm{MC}^{2}$} & ч & $893,00 \pm 182,84$ & $452,27 \pm 68,82$ & $581,88 \pm 99,61$ & $669,63 \pm 82,43$ & $1638,49 \pm 356,51$ \\
\hline & Ж & $604,45 \pm 103,33$ & $366,28 \pm 67,47$ & $373,59 \pm 64,55$ & $518,66 \pm 87,83$ & $741,07 \pm 115,19$ \\
\hline \multirow{2}{*}{$\mathrm{LF}, \mathrm{Mc}^{2}$} & ч & $1306,95 \pm 167,36^{*}$ & $918,68 \pm 139,16^{*}$ & $1177,10 \pm 175,78$ & $907,95 \pm 95,97$ & $1877,98 \pm 217,05$ \\
\hline & ж & $815,66 \pm 130,13$ & $523,38 \pm 91,08$ & $851,97 \pm 121,78$ & $960,72 \pm 145,31$ & $1752,54 \pm 281,30$ \\
\hline \multirow{2}{*}{ VLF,\% } & ч & $27,91 \pm 2,19$ & $46,10 \pm 3,28^{*}$ & $33,71 \pm 2,69$ & $25,10 \pm 2,61$ & $32,58 \pm 2,62$ \\
\hline & ж & $24,58 \pm 2,71$ & $35,73 \pm 3,02$ & $39,28 \pm 3,63$ & $27,40 \pm 2,62$ & $35,10 \pm 3,18$ \\
\hline \multirow{2}{*}{$\mathrm{HF}, \%$} & $\mathrm{Y}$ & $26,62 \pm 1,95$ & $17,66 \pm 1,73^{* *}$ & $21,27 \pm 2,00$ & $30,72 \pm 2,18^{*}$ & $28,33 \pm 2,61^{*}$ \\
\hline & Ж & $29,80 \pm 2,18$ & $25,09 \pm 1,88$ & $18,16 \pm 1,93$ & $24,08 \pm 2,09$ & $20,58 \pm 2,19$ \\
\hline \multirow{2}{*}{$\mathrm{LF}, \%$} & ч & $45,47 \pm 1,97$ & $36,24 \pm 2,51$ & $45,02 \pm 2,38$ & $44,18 \pm 2,34$ & $39,09 \pm 1,93$ \\
\hline & Ж & $45,62 \pm 2,70$ & $39,18 \pm 2,72$ & $42,56 \pm 2,99$ & $47,52 \pm 2,37$ & $44,32 \pm 2,20$ \\
\hline \multirow{2}{*}{$\mathrm{ULF}, \%$} & ч & $0,70 \pm 0,08$ & $0,55 \pm 0,09$ & $0,73 \pm 0,11$ & $0,70 \pm 0,08$ & $0,93 \pm 0,11$ \\
\hline & Ж & $0,54 \pm 0,08$ & $0,63 \pm 0,14$ & $0,56 \pm 0,09$ & $0,64 \pm 0,08$ & $0,78 \pm 0,14$ \\
\hline \multirow{2}{*}{$\begin{array}{c}\text { Індекс } \\
\text { централізації } \\
(\mathrm{HF}+\mathrm{LF}) / \mathrm{VLF}\end{array}$} & ч & $2,58 \pm 0,09 * *$ & $1,17 \pm 0,14^{* *}$ & $1,97 \pm 0,12$ & $2,98 \pm 0,12^{* *}$ & $2,07 \pm 0,12$ \\
\hline & Ж & $3,07 \pm 0,13$ & $1,80 \pm 0,14$ & $1,55 \pm 0,18$ & $2,61 \pm 0,12$ & $1,85 \pm 0,14$ \\
\hline
\end{tabular}

Примітка: $*,{ }^{* *},{ }^{* * *}-$ достовірність різниці середніх значень досліджених груп за критерієм Манна-Уітні відповідно на рівні $p<0,05 ; p<0,01 ; p<0,001$.

Подальші заміри показників ВСР показують відносну їх стабілізацію, що свідчить про вирівнювання енергетичного обміну між досліджуваними особами, хоча i переважна більшість показників свідчать про вищі затрати у жінок в порівнянні 3 чоловіками.

Вазомоторна складова (LF\%) у стані спокою в нормі становить (15-35)\% ТP. Активність вазомоторного центра у жінок перевищує значення для норми в процесі тестових досліджень і, особливо, при тесті на КУКП. Щодо спектральної складової (VLF\%), то вона у нормі становить (15-30\%) ТP і характеризує активність симпатичного відділу вегетативної нервової системи та тісно пов'язана із психоемоційним напруженням і функціональним станом кори головного мозку. У жінок та чоловіків цей стан перевищує значення для норми при навантаженні на ЯДЗ та РPО і зберігається після тестової роботи. При цьому спостерігається достовірне зменшення рівня цього показника під час виконання тесту на

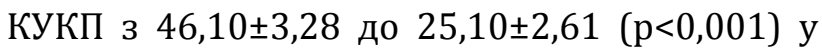
чоловіків та $35,73 \pm 3,02$ до $28,40 \pm 2,62(\mathrm{p}<0,05)$ у жінок.

Отже, направленість змін ВСР при додатковому нервово-емоційному напруженні у осіб обох статей характеризується ростом долі потужності дуже низькочастотної компоненти (VLF \%) при виконанні найскладнішого тесту ЯДЗ, при чому у жінок це явище відбувається і при виконанні менш складного тесту РРО, що свідчить про тривалішу активність симпатичної нервової системи у них. Одночасне зменшення долі низькочастотної компоненти LF та HF при порівнянні 3 вихідним рівнем під час виконання тесту ЯДЗ суттєвіше переважає у чоловіків $(\mathrm{p}<0,01)$, що віддзеркалює ослаблення барорефлекторного та парасимпатичного впливу на серцевосудинну систему. Мабуть такі особливості і 
обумовлюють різкі зміни у парасимпатичній активності за дихальною складовою (HF\%). Так, в структурі спектральної потужності високочастотних хвиль (HF\%) виявлено досить цікаву закономірність. У жінок спостерігається підвищена вагусна активність перед тестовим навантаженням, а у чоловіків вагусна активність підвищена при вирішенні останнього тесту на КУКП і після закінчення тестового навантаження. Тобто, на початкових етапах тестування та до нього цей показник достовірно переважав у жінок, в той час як наприкінці тестового навантаження він достовірно переважав у чоловіків. Про це свідчить динаміка індексу централізації (ІЦ) рис 2.

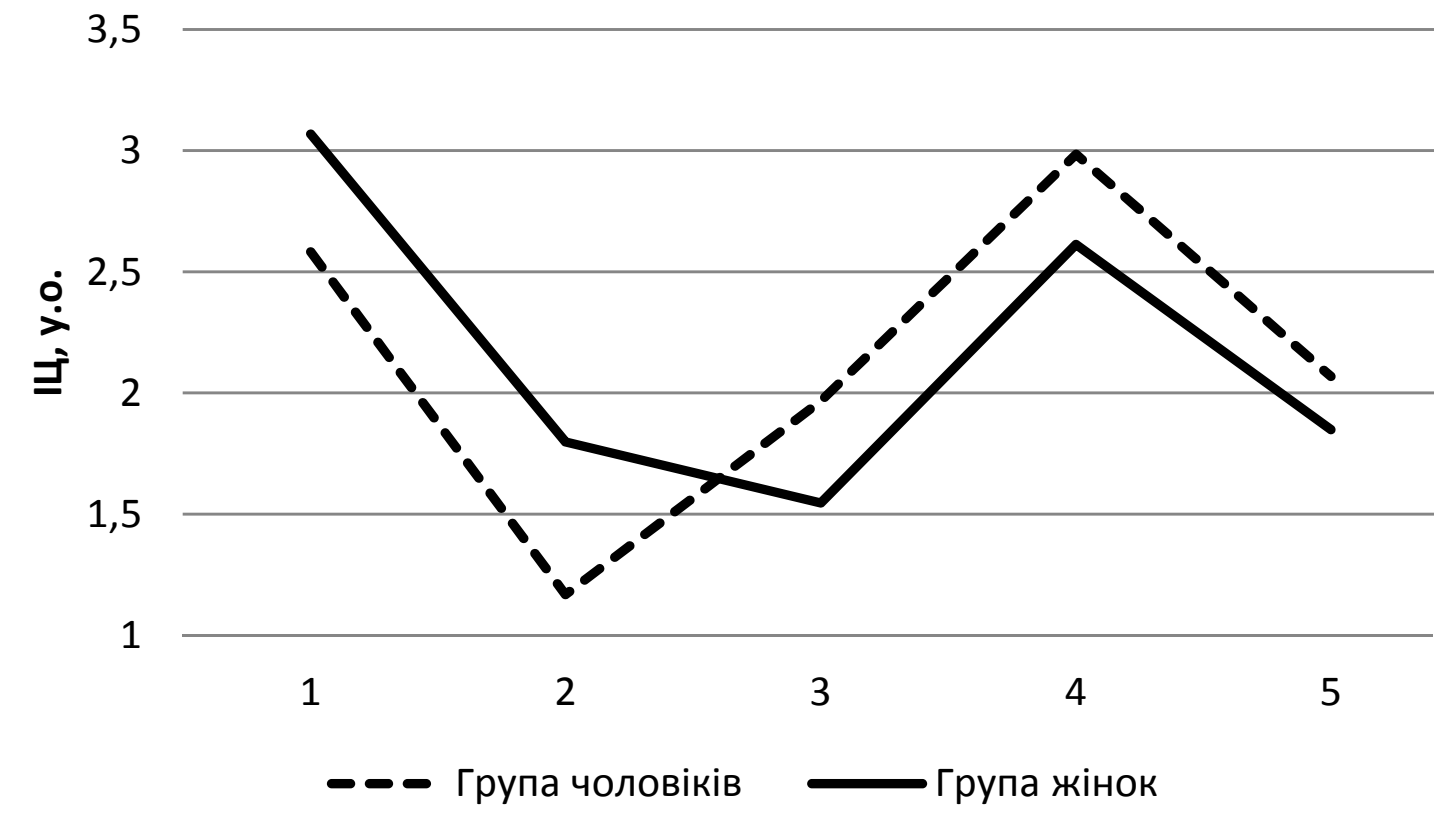

Рисунок 2. Гендерні особливості зміни індексу централізації в різні періоди психофізіологічного навантаження

3 рисунку видно, що ступінь превалювання недихальних складових синусової діяльності серця над дихальними (ІЦ) на початку дослідження та при виконанні тесту на ЯДЗ достовірно вище у осіб жіночої статі. В подальшому це співвідношення змінюється і починає превалювати у чоловіків, що по суті свідчить про превалювання автономного контуру регуляції серцевого ритму над центральним. Тому чоловіки, як правило, мають меншу ймовірність розвитку надлишкової реакції з боку артеріального тиску під час дії інформаційного стресу.

Обговорення. Одержані результати досліджень не суперечать та доповнюють сучасні роботи закордонних вчених в галузі фізіології $[12,13,15,16,17]$. Високий у порівнянні 3 нормою рівень VLF після тестового навантаження у жінок можна трактувати як гіперадаптивну реакцію на навантаження, і чим він вищий, тим стан людини характеризується порушеннями метаболічних i енергетичних процесів в організмі [7].
В даній роботі вперше виявлено, що при різних видах інформаційного навантаження під час операторської діяльності в стані підвищеного нервовоемоційного напруження показники варіабельності серцевого ритму мають відмінності у гендерному аспекті: у жінок стрес-індекс до початку операторської діяльності та під час виконання завдань на якість динамічного запам'ятовування вищий майже у 2 рази за показники у чоловіків $(p<0,001)$, що свідчить про більшу стресочутливість у жінок. Встановлені особливості варіабельності серцевого ритму у військовослужбовців в умовах дії інформаційного стресу різної інтенсивності обумовлюють меншу ймовірність розвитку надлишкової реакції з боку серцево-судинної системи у чоловіків під час дії інформаційного чинника, про що свідчить превалювання парасимпатичного автономного контуру регуляції серцевого ритму над центральним наприкінці усього періоду інформаційного навантаження. 


\section{Висновки}

1. Встановлено, що ціна адаптації до інформаційного стресу у жіноквійськовослужбовців $€$ суттєво вищою $(\mathrm{p}<0,001)$ при комбінованому когнітивному та темпоральному інформаційному навантаженні у порівнянні з чоловіками.

2. Виявлено, що жінкам-військовослужбовцям притаманне значимо вище напруження регуляторних функцій за показниками регуляції серцевого ритму перед незвичними та заздалегідь невідомими умовами діяльності (тестове навантаження) у порівнянні з чоловіками.

\section{Література}

1. Баевский P.М. Математический анализ изменений сердечного ритма при стрессе / Баевский Р.М., Кириллов О.И., Клецкин С.Э. - М.: Наука, 1984.- 214 с.

2. Применение показателя приближенной энтропии (APEN) для оценки регулярности физиологических процессов / Л.М. Бакусов, Р.Х. Зулкарнеев, Ш.З. Загидулин [и др.] // Вестник новых медицинских технологий.- 1998.- Т.5, №3-4.C. $13-15$

3. Данилова Н.Н. Изменения вариабельности сердечного ритма при информационной нагрузке / Н.Н. Данилова, С.В. Астафьев // Журн. высш. нерв. деятельности им. Павлова.- 1999.- Т.49, №1.- С.28.

4. Яблучанский Н. И. Наследственные факторы риска артериальной гипертензии/ Н. И. Яблучанский, Е. Г.Даценко, И. Г. Крайз // Український кардіо логічний журнал. - 2004. - №. 1. - C. 117-121.

5. Кальниш В.В. Удосконалення методології визначення психофізіологічних характеристик операторів / В.В. Кальниш, А.В. Швець // Український журнал з проблем медицини праці. 2008.- T. 16, №4.- С.49-54.

6. Станкус А.И. Вариабельность сердечного ритма при информационных нагрузках / А.И. Станкус, Е.Н. Соколов // Физиол. человека.- 1984.T.10,№ 5.-С.852-857.

7. Флейшман А.Н. Медленные колебания кардиоритма и феномены нелинейной динамики: классификация фазовых портретов, показателей энергетики, спектрального и детрентного анализа. / А.Н. Флейшман // Материалы 3-го Всероссийского симпозиума «Медленные колебательные процессы в организме человека. Теоретические и прикладные аспекты нелинейной динамики, хаоса и фракталов в физиологии и медицине», 21-25 мая 2001 г.- Новокузнецк, 2001.
3. Встановлені особливості впливу інформаційного стресу на енергетичному рівні організації організму військовослужбовців різної статі можуть стати підгрунтям для удосконалення психофізіологічного супроводу та виявлення психофізіологічних механізмів забезпечення високої надійності професійної діяльності військовослужбовців, зокрема жіночої статі, при їх направленні в реальні екстремальні умови виконання службових обов'язків.

- C. $49-61$.

8. Хаспекова Н.Б. Регуляция вариативности ритма сердца у здоровых и больных с психогенной и органической патологией мозга / Н.Б. Хаспекова / Автореф. дис. ... д-ра мед. наук: 03.00.13, Российская Академия наук, институт высшей нервной деятельности и нейрофизиологии. - М. 1996.- 40c.

9. Effects of controlled breathing, mental activity and mental stress with or without verbalization on heart rate variability / L. Bernardi, J. Wdowczyk-Szulc, Valenti [et al.] // J. Am. Coll. Cardiol.- 2000.- V.35, №6.P.1462-1469.

10.Autonomic, neuroendocrine, and immune responses to psychological stress: the reactivity hypothesis / J.T. Cacioppo, G.G. Berntson, W.B. Malarkey [et al.] // Ann. NY Acad. Sci. - 1998.-V.840.P.664-673.

11. Heart Rate Variability. Standards of measurements, physiological interpretation, and clinical use / Task Force of the European Society of Cardiology and the North American Society of Pacing and Electrophysiology // Circulation. - 1996. - Vol. 93. - P. 1043-1065.

12. Madden K. Effects of mental state on heart rate and blood pressure variability in men and women / K. Madden, G.K. Savard // Clinical Physiology .- 1995.V.15, №6.-P.557-569.

13. Heart rate variability and heart rate in healthy volunteers. Is the female autonomic nervous system cardioprotective? / D. Ramaekers, H. Ector, A.E. Aubert [et al.] // Eur Heart J.- 1998.-№9.- P. 1334-1341.

14. Kim H. G. et al. Stress and heart rate variability: A meta-analysis and review of the literature / H. G., Kim, E. J. Cheon, D. S.Bai [et al] //Psychiatry investigation. 2018. - T. 15. - №. 3. - C. 235.

15. Stoney C.M. Sex differences in lipid, lipoprotein, cardiovascular, and neuroendocrine responses to 
acute stress / C.M. Stoney, K.A. Matthews, R.H. McDonald // Psychophysiology.- 1988.- V.25,№6.P.645-656.

16. Tanaka G. Cardiac vagal withdrawal during stressful tasks estimated by the baroreflex sensitivity and respiratory sinus arrhythmia / G. Tanaka, Y. Sawada , R. Fujii // Japanese Journal of Psychology.

\section{References}

1. Bayevskiy, R. M., Kirillov, O. I., \& Semen, Z. K. (1984).Matematicheskiy analiz izmeneniy serdechnogo ritma pri stresse [A mathematical analysis of changes in heart rhythm during stress].Nauka- Science. 214 c. [in Russian].

2. Bakusov, L. M., Zulkarneyev, R. KH., Zagidullin, SH. Z., \& Khafizov, N. KH. (1998). Primeneniye pokazatelya priblizhennoy entropii (APEN) dlya otsenki regulyarnosti fiziologicheskikh protsessov. [Application of the approximate entropy index (APEN) to assess the regularity of physiological processes.] Vestnik novykh meditsinskikh tekhnologiy - Herald of New Medical Technologies, 5(5), 14-27. [in Russian].

3. Danilova, N. N., \& Astaf'yev, S. V. (1999). Izmeneniye variabel'nosti serdechnogo ritma pri informatsionnoy nagruzke. [Changes in heart rate variability with the information load.] Zhurnal vysshey nervnoy deyatel'nosti, - Journal of Higher Nervous Activity 49(1), 28-38. [in Russian].

4. Yabluchanskiy, N. I., Datsenko, Ye. G., \& Krayz, I. G. (2004). Nasledstvennyye faktory riska arterial'noy gipertenzii. [Hereditary risk factors for hypertension] Ukrains'kiy kardiologichniy zhurnal - Ukrainian Cardiological Journal, (1), 117-121 [in Russian].

5. Kalnish, V. V., \& Shvets, A. V. (2008). Udoskonalennya metodologii viznachennya psikhofiziologichnikh kharakteristik operatoriv.[ Improvement of the methodology for determining the psychophysiological characteristics of operators] Ukrains'kiy zhurnal z problem meditsini pratsi Ukrainian Journal of Occupational Health, (4), 49-54. [in Ukrainian].

6. Stankus, A. I., \& Sokolov, Ye. N. (1984). Variabel'nost' serdechnogo ritma pri informatsionnykh nagruzkakh. [Heart rate variability with information loads]. Fiziologiya cheloveka Human Physiology, 10(5), 852-858. [in Russian].

7. Fleyshman, A. N. (2001). Medlennyye kolebaniya kardioritma i fenomeny nelineynoy dinamiki. [Slow vibrations of heart rate and non-linear dynamics phenomena] Mater - Conference Mater, 3, 49-61. [in Russian]

8. Khaspekova, N. B. (1996). O variativnosti ritma serdtsa u zdorovykh i bol'nykh s psikhogennoy i organicheskoy patologiyey mozga [About the variability of the heart rhythm in healthy and patients with psychogenic and organic brain pathology.]. Autoref. doct. diss., M. 40. [in Russian].
- 1994.-V.65, № 1.-P.9-17.

17. Gibbons S. W. Gender differences in response to deployment among military healthcare providers in Afghanistan and Iraq. / S. W. Gibbons, E. J. Hickling, S. D. [et al] // Journal of women's health. - 2012.- V. 21, №5. - P. 496-504. doi:10.1089/jwh.2011.3097.

9. Bernardi, L., Wdowczyk-Szulc, J., Valenti, C., Castoldi, S., Passino, C., Spadacini, G., \& Sleight, P. (2000). Effects of controlled breathing, mental activity and mental stress with or without verbalization on heart rate variability. Journal of the American College of Cardiology, 35(6), 1462-1469.

10. Cacioppo, J. T., Berntson, G. G., Malarkey, W. B., KIECOLT-GLASER, J. K., Sheridan, J. F., Poehlmann, K. M., ... \& Glaser, R. (1998). Autonomic, neuroendocrine, and immune responses to psychological stress: The reactivity hypothesisa. Annals of the New York Academy of Sciences, 840(1), 664-673.

11. Electrophysiology, Task Force of the European Society of Cardiology the North American Society of Pacing. (1996). Heart rate variability: standards of measurement, physiological interpretation, and clinical use. Circulation, 93(5), 1043-1065.

12. Madden, K., \& Savard, G. K. (1995). Effects of mental state on heart rate and blood pressure variability in men and women.Clinical Physiology, 15(6), 557-569.

13. Ramaekers, D., Ector, H., Aubert, A. E., Rubens, A., \& Van de Werf, F. (1998). Heart rate variability and heart rate in healthy volunteers. Is the female autonomic nervous system cardioprotective?. European heart journal, 19(9), 1334-1341.

14. Kim, H. G., Cheon, E. J., Bai, D. S., Lee, Y. H., \& Koo, B. H. (2018). Stress and heart rate variability: A metaanalysis and review of the literature. Psychiatry investigation, 15(3), 235.

15. Stoney, C. M., Matthews, K. A., Mcdonald, R. H., \& Johnson, C. A. (1988). Sex differences in lipid, lipoprotein, cardiovascular, and neuroendocrine responses to acute stress. Psychophysiology,25(6), 645656.

16. Tanaka, G., Sawada, Y., \& Fujii, R. (1994). Cardiac vagal withdrawal during stressful tasks estimated by the baroreflex sensitivity and respiratory sinus arrhythmia. Shinrigaku kenkyu: The Japanese journal of psychology, 65(1), 9-17.

17. Gibbons, S. W., Hickling, E. J., Barnett, S. D., Herbig-Wall, P. L., \& Watts, D. D. (2012). Gender differences in response to deployment among military healthcare providers in Afghanistan and Iraq. Journal of women's health, 21(5), 496-504. doi:10.1089/jwh.2011.3097. 


\title{
ГЕНДЕРНЫЕ ОСОБЕННОСТИ РЕГУЛЯЦИИ СЕРДЕЧНОГО РИТМА У ВОЕННОСЛУЖАЩИХ В УСЛОВИЯХ ДЕЙСТВИЯ ИНФОРМАЦИОННОГО СТРЕССА РАЗЛИЧНОЙ ИНТЕНСИВНОСТИ
}

\author{
А.В. Швец \\ Украинская военно-медицинская академия, Киев
}

Введение. Изучение гендерных особенностей влияния информационного стресса различной интенсивности на регуляторные функции организма военных операторов является актуальным в связи вступлением в силу Закона о равных правах женщин и мужчин на военной службе в Вооруженных Силах Украины и других военных формированиях и их активным привлечением женщин военнослужащих $к$ экстремальным условиям служебной деятельности.

Цель работы - выявление гендерных особенностей изменений вариабельности сердечного ритма у военнослужащих, находящихся в состоянии повышенного нервно-эмоционального напряжения вследствие влияния информационного стресса различной интенсивности.

Материалы и методы. Исследовано 73 здоровых военнослужащие женского и мужского пола в возрасте 22-25 лет (из них 58\% мужчины). Для решения поставленной цели разработаны адекватную модель стрессогенного влияния, где в качестве стрессогенных нагрузки использовали действие информационного фактора различной интенсивности. Изучение вариабельности сердечного ритма проводили с помощью аппаратно-программного комплекса «Саrdio Sens» к применению информационной нагрузки, в течение обработки человеком различной по сложности и содержанию информации, а также после информационной нагрузки. Анализ полученных результатов проводился методами вариационной статистики, дисперсионного анализа с помощью пакета программ STATISTICA 8.0.

Результаты. Установлено, что у женщин стресс-индекс до начала процедуры тестирования и при выполнении задач на качество динамического запоминания выше почти в 2 раза показателей у мужчин $(p<0,001)$, что свидетельствует о большей стрессочувствительности у женщин. Отличительной особенностью в структуре спектральной мощности высокочастотных волн (НF) у женщин является повышенная вагусная активность перед началом тестирования, а у мужчин вагусная активность превалирует в конце и после его окончания, что свидетельствует о более длительной активности симпатической нервной системы у них. Установлены особенности вариабельности сердечного ритма у военнослужащих в условиях действия информационного стресса различной интенсивности обусловливают меньшую вероятность развития избыточного реакции со стороны сердечно-сосудистой системы у мужчин во время действия информационного фактора, о чем свидетельствует преобладание парасимпатического автономного контура регуляции сердечного ритма над центральным в конце всего периода информационного нагрузки.

Выводы. Доказано, что цена адаптации к информационному стрессу у женщин-военнослужащих существенно выше при комбинированной когнитивной и темпоральной информационной нагрузке по сравнению с мужчинами. Отмечено значимое напряжение регуляторных функций перед необычными и заранее неизвестными условиями деятельности. Установлены особенности влияния информационного стресса на энергетическом уровне организации организма военнослужащих разного пола могут стать основой для совершенствования психофизиологического сопровождения и обнаружения психофизиологических механизмов обеспечения высокой надежности профессиональной деятельности военнослужащих и, в частности женщин, при их направлении в реальные экстремальные условия выполнения служебных обязанностей.

Ключевые слова: вариабельность сердечного ритма, психофизиологическое состояние, гендерные особенности, информационный стресс, военнослужащие.

\section{GENDER CHARACTERISTICS OF HEART RATE REGULATION AMONG SERVICEMEN UNDER INFLUENCE OF DIFFERENT INTENSITY INFORMATIONAL STRESS}

\author{
A.V. Shvets \\ Ukrainian Military Medical Academy, Kyiv
}

Introduction. The study of gender peculiarities of the influence of different intensity informational stress on the regulatory functions of the body of military operators is relevant in connection with the ratification of the Law on Equal Rights of Women and Men in the Military Service of the Armed Forces of Ukraine and other military formations and active women involvement as servicemen to extreme conditions service. 
The purpose of the study is to identify the gender peculiarities in heart rate variability changes among servicemen who are working under increased nervous-emotional stress state due to influence of varying intensity informational stress.

Materials and methods. 73 healthy male and female servicemen aged 22-25 were studied (58\% of them were men). An adequate model of stressful influence to achieve the study goal has been developed, where the effect of the information factor of different intensity was used as a stress-related load. The study of the heart rate variability was carried out with the help of the hardware and software complex "Cardio Sens" before the use of information load, during information processing by a person in different terms of complexity and content of information, as well as after the information load. The analysis of the results was carried out using the methods of descriptive statistics, dispersion analysis with the software STATISTICA 8.0.

Results. It was found that in women, the stress-index before the start of the testing procedure and during tasks on the quality of dynamic memorization is more than twice as high as among men $(p<0.001)$, which indicates greater stress in women. A distinctive feature in the structure of the spectral power of high-frequency waves (HF) is increased vagal activity before the start of testing among women, and vagal activity prevails in the end and after its end in men. It indicates longer duration of sympathetic nervous system activity among them. The peculiarities of servicemen heart rate variability under influence of different intensity informational stress determine the lower probability of excessive reaction growth from the cardiovascular system in men during the information factor action, as evidenced by the prevalence of the parasympathetic autonomous contour of regulation of the heart rate over the central contour at the end of the entire period of information load.

Conclusions. It has been proved that the "adaptation price" to information stress among military women was significantly higher at combined cognitive and temporal information load compared to men. It was noted the significant tension of regulatory functions in unusual and previously unknown conditions of activity (test load). The established peculiarities of the influence of information stress on the energy level of different gender body functioning can become the basis for the improvement of psychophysiological support and the identification of psychophysiological mechanisms for ensuring high reliability of military personnel performance, and especially women, in case their deployment to real extreme conditions of combat environment. servicemen.

Key words: heart rate variability, psychophysiological state, gender characteristics, information stress,

\section{Відомості про авторів:}

Швець А. В., полковник медичної служби, д-р мед. наук, старший науковий співробітник, заступник начальника Української військово-медичної академії з наукової роботи, м. Київ,

\section{Сведения об авторах:}

Швец А. В., полковник медицинской службы, д-р мед. наук, старший научный сотрудник, заместитель начальника Украинской военно-медицинской академии по научной работе, г. Киев.

\section{Information about authors:}

Shvets A. V., Col. MS, MD, PhD, DSc, Senior Researcher, Deputy chief of Ukrainian Military Medical Academy for sciense, Kyiv, E-mail: shvetsandro@gmail.com, https://orcid.org/0000-0002-9461-7129.

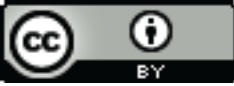

Адреса для листування: вул. Московська, 45/1, буд. 33, м. Київ 01015 